11 Thomas M, Peters TJ. Acetaldehyde: its role in alcoholic toxicity and dependence. $\mathrm{Br} \mathcal{f}$ Addict 1981;76:375-8.

12 Eriksson CJP. The role of acetaldehyde in drinking behaviour and tissue damage. British fournal on Alcohol and Alcoholism 1982;17:57-69.

13 Lewis KO, Paton A. Could superoxide cause cirrhosis? Lancet 1982;i: 188-9.

14 Heys AD, Dormandy TL. Lipid peroxidation in iron-overloaded spleens. Clin Sci 1981;60: 295-301.

15 Fairshter RD. Paraquat toxicity and lipid peroxidation. Arch Intern Med 1981;141:1121-2.

16 Donohue TM Jr, Tuma DJ, Sorrell MF. Acetaldehyde adducts with proteins: binding of $\left[{ }^{14} \mathrm{C}\right]$ acetaldehyde to serum albumin. Arch Biochem Biophys 1983;220:239-46.

17 Stevens VJ, Fantl WJ, Newman CB, Sims RV, Cerami A, Peterson CM. Acetaldehyde adducts with hemoglobin. $\mathcal{F}$ Clin Invest 1981;67:361-9.

18 Gaines KC, Salhany JM, Tuma DJ, Sorrell MF. Reaction of acetaldehyde with human erythrocyte membrane proteins. FEBS Lett 1977;75:115-9.

19 Medina VA, Donohue TM Jr, Sorrell MF, Tuma DI. Covalent binding of acetaldehyde to hepatic proteins during ethanol oxidation. F Lab Clin Med 1985;105:5-10.

20 Cederbaum AI, Lieber CS, Rubin E. The effect of acetaldehyde on mitochondrial function. Arch Biochem Biophys 1974;161:26-39.

21 Burke JP, Rubin $E$. The effects of ethanol and acetaldehyde on the products of protein synthesis by liver mitochondria. Lab Invest 1979;41:393-400.

22 Schreiber SS, Oratz M, Rothschild MA, Reff F, Evans C. Alcoholic cardiomyopathy. II. The inhibition of cardiac microsomal protein synthesis by acetaldehyde. $7 \mathrm{Mol}$ Cell Cardiol 1974;6:207-13.

23 Perin A, Scalabrino G, Sessa A, Arnaboldi A. In vitro inhibition of protein synthesis in rat liver as a consequence of ethanol metabolism. Biochim Biophys Acta 1974;366:101-8.

24 Tuma DJ, Zetterman RK, Sorrell MF. Inhibition of glycoprotein secretion by ethanol and acetaldehyde in rat liver slices. Biochem Pharmacol 1980;29:35-8.

25 Wickramasinghe SN, Malik F. Acetaldehyde causes a prolongation of the doubling time and an increase in the modal volume of cells in culture. Alcoholism: Clinical and Experimental Research 1986;10:350-4.

26 Bond AN, Wickramasinghe $S N$. Investigations into the production of acetate from ethanol by human blood and bone marrow cells in vitro. Acta Haematol 1983;60:303-13.

27 Wickramasinghe SN. Rates of metabolism of ethanol to acetate by human neutrophil precursors and macrophages. Alcohol Alcohol 1985;20:299-303.

28 Wickramasinghe SN. Observations on the biochemical basis of ethanol metabolism by human macrophages. Alcohol Alcohol 1986;21:57-63.

29 Wickramasinghe SN, Barden G, Levy L. The capacity of macrophages from different murine tissues to metabolise ethanol and generate an ethanol-dependent non-dialysable cytotoxic activity in vitro. Alcohol Alcohol (in press).
30 Wickramasinghe $\mathrm{SN}$. Supernatants from ethanol-containing macrophage cultures have cytotoxic activity. Alcohol Alcohol 1986;21:263-8.

31 Wickramasinghe SN, Gardner B, Barden G. Cytotoxic protein molecules generated as a consequence of ethanol metabolism in vitro and in vivo. Lancet 1986;ii:823-6.

32 De Master EG, Redfern B, Weir EK, Pierpont GL, Crouse LJ. Elimination of artifactual acetaldehyde in the measurement of human blood acetaldehyde by the use of polyethylen glycol and sodium azide: normal blood acetaldehyde levels in the dog and human after ethanol. Alcoholism: Clinical and Experimental Research 1983;7:436-42.

33 Lee S-H, Starkey PM, Gordon S. Quantitative analysis of total macrophage content in adult mouse tissues. Immunochemical studies with monoclonal antibody F4/80. $f$ Exp Med 1985;161: 475-89.

34 Brewin TB. The incidence of alcohol intolerance in women with tumours of the uterus, ovary or breast. Proceedings of the Royal Sociery of Medicine 1967;60:1308-9.

35 Greengard O, Federman M, Knox WE. Cytomorphometry of developing rat liver and its application to enzymic differentiation. I Cell Biol 1972;52:261-72.

36 Wisse E, Knook DL. The investigation of sinusoidal cells: a new approach to the study of liver function. In: Popper H, Schaffner F, eds. Progress in liver diseases. Vol 6. New York: Grune and Stratton, 1979:153-71.

37 Gates GA, Henley KS, Pollard HM, Schmidt E, Schmidt FW. The cell population of human liver. f Lab Clin Med 1961;57:182-4.

38 Wickramasinghe SN. Neuroglial and neuroblastoma cell lines are capable of metabolizing ethanol via an alcohol-dehydrogenase-independent pathway. Alcoholism: Clinical and Experimental Research (in press)

39 Sanchis R, Sancho-Tello M, Guerri C. The effects of chronic alcohol consumption on pregnant rats and their offspring. Alcohol Alcohol 1986;21:295-305.

40 Linch DC, Knott LJ, Rodeck CH, Huehns ER. Studies of circulating hemopoietic progenitor cells in human fetal blood. Blood 1982;59:976-9.

41 Fukuda T. Fetal hemopoiesis. I. Electron microscope studies on human yolk sac hemopoiesis. Virchows Arch [Cell Pathol] 1973;14:197-213.

42 Rimland D. Mechanisms of ethanol-induced defects of alveolar macrophage function. Alcoholism: Clinical and Experimental Research 1983;8:73-6.

43 Galante D, Andreana A, Perna P, Utili R, Ruggiero G. Decreased phagocytic and bactericidal activity of the hepatic reticuloendothelial system during chronic ethanol treatment and its resolution by levamisole. Fournal of the Reticuloendothelial Society 1982;32:179-87.

44 Nolan JP, Camara DS. Endotoxin and liver disease. In: Knook DL, Wisse E, eds. Sinusoidal liver cells. Amsterdam: Elsevier Biomedical Press, 1982:377-86.

(Accepted 5 February 1987)

\title{
Letter from Amsterdam
}

\section{Inner city care}

\section{ROBIN HULL}

In a recent Independent Television documentary on the acquired immune deficiency syndrome (AIDS) two Edinburgh prostitutes were interviewed. Both knew that they were seropositive to the human immune virus (HIV) but made it clear that for them "it was business as usual." The Roman phrase caveat emptor might, had their classical education been better, have tripped from their lips. But how many buyers are wary, particularly when spending in the brothel?

On another occasion boys infected with the virus acquired from homosexual prostitution since childhood went further. They were so embittered by having caught the disease that they were determined to give it to as many people as possible before they died from it. This was their revenge against a society that had hardly treated them well.

No one can condone such attitudes but they are as understandable and pathetically futile as Jewish gestures of defiance at Auschwitz or Babi Yar. Rather than the pseudoreligious denunciation of human beings whose behaviour patterns are abhorrent to us that we hear from some quarters, we should try to understand and to help. We

Institute of General Practice, Free University, 1007 MC Amsterdam ROBIN HULL, MB, FRCGP, professor of general practice can do little about this new disease, which, like syphilis, plague, cholera, and typhus, may have as profound an effect on world history as the discovery of nuclear fission, but we may be able to control its spread. The most important vector is promiscuous sexual behaviour. The British government has invested enormous sums of money into education of consumers of commercial sex and is to be commended on its teaching campaign, since evidence from America suggests that alteration of sexual practice has coincided with a slight reduction in the rate of increase of the AIDS pandemic. But the consumer of commercial sex is only one of the pair; what about the provider-the male or female prostitute, whose business is promiscuity. If these providers take the attitude of the Edinburgh prostitutes of the television interview then the infection rate will increase. We need, therefore, not just to educate the occasional consumer but the habitual provider. That is not an easy task but at least one attempt is being made in the red light district of Amsterdam.

\section{Oldest profession in the oldest street}

Some 20 years ago a mission was established in the Ouderzijds Achterburgwal-one of the oldest streets in Amsterdam. With its long history as a major port Amsterdam has always offered 
hospitality to sailors. That means a tradition of inns and bordellos. Most of these activities are centred on the oldest quarter of the town, where once fine seventeenth century merchants' houses have been adapted as sex shops, erotic theatres, and cabins where nearly naked girls stand bathed in the rosy light of their trade. A man with elegant American English stops one in the street and, as if he were a salesman for fine wines, describes the hard porn he offers within: "No ordinary stuff this, real penetration and ejaculation by 17 year olds who really go...." There are enough voyeurs among the tourists to accept his invitation; one thing may lead to another, and, such is human nature, to later sexually transmitted disease. One wonders how many of the young tourists who throng these streets in the summer heed Mr Fowler's broadcast advice.

The mission is a remarkable place. The vicarage is a former brothel and the tiny church was once a sex theatre. The church has a brick floor patterned with concentric circles representing the message of the mission spreading in rings across the floor ignoring walls and rippling even into the street outside. The mission demonstrates its interdenominational nature by a complex font formed by a running stream through the church and affectionately referred to as the River of Jordan. This allows different styles of baptism, appropriate to the many sects who frequent this ecumenical oasis, from the slightest moisture through liberal sprinkling to the total immersion of the Baptists, and fine old icons on the walls welcome the Orthodox.

Before its religious and sexual functions the old canal house was the home of a rich merchant, and traces of his incumbency remain in faded decor and plaster work. The house must have served many purposes and has been much adapted. Its earliest history was also religious and excavations have revealed a crypt, thought to be of the twelfth century and part of an ancient monastery. "Here," the pastor said, "they must have held all night vigils against the pest, the Black death; now we do the same against the new pest.... Only today another of our community was found to be seropositive."

The medical care of the red light district has traditionally been provided by a mixture of health workers from the municipality, the casualty departments of a number of local hospitals, and a few dedicated general practitioners who work in the area. But recently several local hospitals have closed, and medical facilities have become stretched. Many of the people living in this sleazy area are out of work, drug addicts, or illegal immigrants. The poverty and destitution are so apalling that when I commented that this was the Third World in Amsterdam I was corrected: "No, this is worse; this is the fourth world." So it may be very difficult for some of these people to gain access to primary care and for this reason the mission opened its own clinic at the beginning of 1983 . The clinic opens at $5 \mathrm{pm}$, stays open until $2 \mathrm{am}$, and offers care for anyone who steps in off the streets. Work was slow to begin with-the clinic averaged only about 150 patients a month during the first year-but by 1985 it was seeing over 6000 a year in the evening session. In the summer of 1985 a two hour morning clinic was started, which soon catered for as many or more patients than the evening clinic.

The staff consists mostly of volunteers, whose only recompense is free accommodation in the mission. One is a young Dutch doctor married to an American accountant, who had worked here as a student and came back with her husband. Another is a retired missionary from India who helps in the evening. The doctor who runs the morning clinic is paid a salary by a fund from Amsterdam churches. Last summer an American nurse called at the clinic for help with her sore throat and stayed to help; there is a 17 year old English girl from Birmingham working temporarily before going home to start nursing training and other nurses are Dutch and
Indonesian. The male receptionists tend to be young and fairly robust; some of the clients are violent, and the women doctors, sometimes alarmed at their outbursts, are grateful for receptionists who may have to combine the role of bouncer with that of helping patients.

\section{Refugees}

The day book records the nationality of patients. Among 164 patients there were 32 nationalities; of these, $30 \%$ were Dutch, $12 \%$ Indian, and $10 \%$ German, with British, Moroccan, and Turkish not far behind at $4 \%$ each. But there were also refugees from Uganda and Angola, Iran and Iraq, Afghanistan, Palestine, and Ceylon-as well as the hungry Horn of Africa. One of the receptionists said: "two or three months after war breaks out anywhere in the world the people from that country turn up here." So two fifths of the clients are refugees and another fifth unemployed, uninsured Dutch. Many are illegal immigrants from other parts of Europe and a few are simply tourists who drop in for medical care because the clinic is entered in a popular guide on How to Survive in Europe on $\$ 5$ a Day.

On a January night I joined the workers at the mission clinic. The canals were frozen solid; outside the temperature was $-15^{\circ} \mathrm{C}$ and the east wind chilled that to $-30^{\circ} \mathrm{C}$. Trade was slow in the streets; the sex shops were empty and the girls in the windows offered their warmth to very few street walkers. This was a bad night to be homeless. One man has been sleeping out for 14 days; his hands are swollen, his fingers banana like oedematous bullae whose nails are deeply cyanosed with frostbite. He is a benzodiazepine habituate and well known at the clinic. After some debate one of the doctors drives him to the teaching hospital, where he is admitted.

A German of 31 comes asking for sleeping tablets. He speaks good English and is quite well dressed but, like the others, has his problems. A former heroin addict, now weaned to methadone, he has been in the Netherlands for 10 years; as an electronics dealer he used to work in the dockyards but is now out of work and reliant on social security. Recently he has been under the care of the Amsterdam municipal health scheme, who provide him with methadone and have been investigating a shadow on his lung. All he wants, he keeps insisting, is some sleeping tablets since he lies in bed all day thinking. The doctor is not very impressed by this tale but reluctantly provides a few benzodiazepine sleeping pills.

There is an invasion of Sikhs, all refugees from the Punjab (or, as they prefer to say, from Khalistan). All prefer the uncertain charity of Amsterdam to the religious persecution at home. One has pain in his ear, another a trivial scald; others have reactions to the intense cold, and all want medicine to make them better. It is difficult to explain to these simple peasants from half a world away that nothing other than time is needed to effect complete cure.

So an evening surgery at the mission continues late into the night with a multitude of trivial (and a few serious) medical conditions presented by people with the most appalling social problems. These little medical problems are cries for help, made, half hoping that they will not be heard, by human beings who have almost given up belief that their fellow men will aid them and whose wish for help is little stronger than their hope of rejection so that they may have reason to sink again into the morass of their hopelessness. There is only one hope for these people and at that a slim one: it is love, that charity that St Paul linked with faith and hope, which the Amsterdam mission is so criticised for offering.

Of all the care I have seen in the Netherlands, it is this that most needs support. 